\title{
COMPARISON AMONG TOMATO JUICE AGAR WITH OTHER THREE MEDIA FOR DIFFERENTIATION OF Candida dubliniensis FROM Candida albicans
}

\author{
Sydney Hartz ALVES(1), Érico Silva de LORETO(2), Carlos Eduardo LINARES(2), Carolina P. SILVEIRA(3), Liliane A. SCHEID(3), \\ Daniela I. Brayer PEREIRA(1) \& Janio Morais SANTURIO(1)
}

\begin{abstract}
SUMMARY
The purpose of the present study is to compare the tomato juice agar, a well known medium employed to observe ascospore formation, with niger seed agar, casein agar and sunflower seed agar, applied to a differentiation between $C$. dubliniensis and $C$. albicans. After 48 hours of incubation at $30{ }^{\circ} \mathrm{C}$ all 26 (100\%) C. dubliniensis isolates tested produced chlamydospores on tomato juice agar as well as in the other three media evaluated. However, when we inoculated all media with $C$. albicans, the absence of chlamydospores became resulting in the following percents: tomato juice agar (92.47\%), niger seed agar (96.7\%), casein agar $(91.39 \%)$, and sunflower seed agar $(96.7 \%)$. These results indicate that tomato juice agar is another medium which can also be used in the first phenotypic differentiation between $C$. dubliniensis and C. albicans.
\end{abstract}

KEYWORDS: Candida dubliniensis; Tomato juice agar; Phenotypic identification.

\section{INTRODUCTION}

Candida dubliniensis is a newly described fungus which was first reported by SULLIVAN et al. in $1995^{21}$. C. dubliniensis is phylogenetically closely related to $C$. albicans, thereby sharing many morphological and physiological characteristics as germ tube positive, similar biochemical patterns and the ability to form chlamydospores in rice extract agar and cornmeal agar ${ }^{21,22}$.

Routine discrimination between $C$. dubliniensis and the closely related species $C$. albicans has been problematic ${ }^{21,22}$. The most accurate method of identifying $C$. dubliniensis and discriminating it from $C$. albicans requires PCR-based tests ${ }^{8,12,21,22}$; however, these are not readily applicable to the high-volume throughput of isolates in many diagnostic laboratories routine $\mathrm{e}^{2,3,14}$

The most reliable phenotypic methods for the identification of $C$. dubliniensis include carbohydrate assimilation profile analysis by using commercially available yeast identification systems $\mathrm{s}^{5,7}$ and detection of differential antigen expression through immunofluorescence microscopy ${ }^{6}$. However, they can only be applied after the first isolation.

One of the key features employed in the initial description of $C$. dubliniensis was its ability to produce abundant chlamydospores on corn meal agar and rice-agar-Tween medium ${ }^{21}$. Based on this characteristic, recently new media as niger seed $\operatorname{agar}^{20}$, caffeic-acid- ferricitrate agar ${ }^{2}$, casein $\operatorname{agar}^{14}$, sunflower seed $\operatorname{agar}^{3}$ and tobacco $\operatorname{agar}^{10}$ have been proposed to differentiate both species simultaneously up to the first isolation.

In the last ten years there has been a proliferation of phenotypic tests in the literature for the differentiation of $C$. albicans and $C$. dubliniensis which includes carbohydrate assimilation profile ${ }^{5,7}$, appearance on CHROMagar ${ }^{11}$, ability to grow at $45{ }^{\circ} \mathrm{C}^{16}$, inability to grow on Sabouraud dextrose broth with $\mathrm{NaCl} 6.5 \%{ }^{4}$, absence of an opacity halo around an inoculated site on Tween 80 medium $^{19}$ and some others ${ }^{6,15,18}$

Tomato juice agar or V-8 juice agar is a well known medium widely used for ascospore formation in yeasts as Saccharomyces cerevisae and Hansenula anomala ${ }^{1,9,13}$.

Here we compare the tomato juice agar (V8 agar) with niger seed agar, casein agar and sunflower agar applied to differentiation between C. dubliniensis and C. albicans.

\section{MATERIAL AND METHODS}

Strains: a total of 26 Brazilian C. dubliniensis isolates and $93 C$. albicans isolates were studied. C. albicans isolates were from the culture collection of the Laboratório de Pesquisas Micológicas, Department of Microbiology and Parasitology, Universidade Federal 


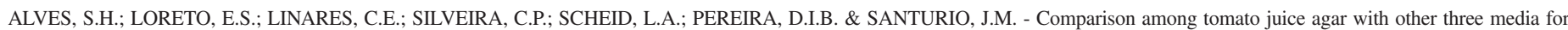
differentiation of Candida dubliniensis from Candida albicans. Rev. Inst. Med. trop. S. Paulo, 48(3):119-121, 2006.

de Santa Maria, Santa Maria city, RS, Brazil. C. dubliniensis were from different Brazilian cities. All the $C$. dubliniensis isolates were rigorously identified by phenotypic and genotypic methods ${ }^{8,12,20,21}$. The strains were stored in frozen stocks at $-80^{\circ} \mathrm{C}$ and were routinely propagated on YPD agar plate $(10 \mathrm{~g}$ yeast extract, $20 \mathrm{~g}$ peptone, $20 \mathrm{~g}$ glucose, $15 \mathrm{~g}$ agar per litre) at $30^{\circ} \mathrm{C}^{13}$.

Culture media for chlamydospores production: a) Tomato juice agar $^{17}$ (tomato juice $200 \mathrm{~mL}$; $\mathrm{CaCO}_{3} 3 \mathrm{~g}$; dextrose $5 \mathrm{~g}$; agar $20 \mathrm{~g}$ per liter); b) Niger seed $\operatorname{agar}^{20}$ (50 g Guizotia abyssinica seed pulverized; $1 \mathrm{~g}$ glucose; $1 \mathrm{~g} \mathrm{KH} \mathrm{PO}_{4} ; 1 \mathrm{~g}$ creatinine; $15 \mathrm{~g}$ agar per liter); c) Sunflower seed agar $^{3}$ (extract cooled and filtered from $50 \mathrm{~g}$ Helianthus annuus pulverized; $1 \mathrm{~g}$ glucose; $1 \mathrm{~g} \mathrm{K \textrm {K } _ { 2 }} \mathrm{PO}_{4} ; 1 \mathrm{~g}$ creatinine and $15 \mathrm{~g}$ agar per liter); d) Casein $\operatorname{agar}^{14}$ (10 g of skim milk was dissolved in $90 \mathrm{~mL}$ of distilled water, and $3 \mathrm{~g}$ of agar was dissolved in $97 \mathrm{~mL}$ of distilled water. After autoclaving both solutions separately at $121{ }^{\circ} \mathrm{C}$ for 15 min, they were allowed to cool to $45{ }^{\circ} \mathrm{C}$ to $50{ }^{\circ} \mathrm{C}$ and after this were mixed together. All the media after autoclaving were dispensed in 25 $\mathrm{mL}$ amounts into $90 \mathrm{~mm}$-diameter Petri dishes. Tomato juice agar, niger seed agar, sunflower agar and casein agar plates were inoculated with culture growth in a $48 \mathrm{~h}$ YPD agar followed by incubation at $30{ }^{\circ} \mathrm{C}$, except casein agar, which was incubated at $24^{\circ} \mathrm{C}$. Following the incubation, the plates were directly examined by $10 \mathrm{X}$ and $40 \mathrm{X}$ objectives lens to observe the chlamydospores. When absent, samples of culture growth were stained with lactophenol cotton blue and were again examined for chlamydospores production by light microscopy.

\section{RESULTS AND DISCUSSION}

All the $26(100 \%)$ C. dubliniensis isolates tested produced chlamydospores in Tomato juice agar after $48 \mathrm{~h}$ of incubation at 30 ${ }^{\circ} \mathrm{C}$. The majority of C. albicans isolates evaluated (92.47\%) did not show chlamydospores in the same conditions. However, in the cases that chlamydospores were produced by $C$. albicans, although indistinguishable from those by $C$. dubliniensis, were difficult to observe due to their very low number. When we compared the four media for $C$. dubliniensis identification based on chlamydospore production, we observed that all $C$. dubliniensis isolates tested $(\mathrm{n}=$ 26) produced chlamydospores, yielding $100 \%$ of sensibility. On the other hand, when we inoculated all media with $C$. albicans isolates (n $=93$ ), the production of chlamydospores was very little: tomato juice agar 7/93, niger seed agar 3/93, sunflower agar 3/93 and casein agar 8/ 93, which have resulted in specificities ranging from $91 \%$ to $97 \%$.

C. dubliniensis is usually isolated in mixed cultures with $C$. albicans and/or other yeasts. The difficulty in detecting mixed cultures in plates with traditional media as Sabouraud dextrose agar has stimulated the development of identification systems and differential media for yeasts ${ }^{1,9,13,17}$. Specific media is being purposed to discriminate $C$. dubliniensis from $C$. albicans such as the niger seed agar (Guizotia abyssinica) ${ }^{20}$, the sunflower agar (Helianthus annuus $)^{3}$ and casein agar $^{14}$ among others ${ }^{2,10,11,19}$. They are simple and cheap methods for presumptive differentiation of $C$. dubliniensis from $C$. albicans, showing satisfactory results. However, it is well established that $C$. dubliniensis isolates present great phenotypic variability, what hinders the standardization of the identification techniques ${ }^{2,5,7,11,16,21}$; so the search for new and more refined methods are advantageous and should be stimulated. Here we have studied the tomato juice agar which is a traditional medium employed to observe the formation of ascus to differentiate the sexual reproduction as seen in Saccharomyces cerevisae from the asexual reproduction in yeasts like Candida species $^{1,9,13,17}$. We noticed that tomato juice agar stimulates the chlamydospore production in $C$. dubliniensis similarly to what occurs with other media. Chlamydospores, from greek chlamys that means mantle, plus spora that means seed or spore, is a thick-walled thallic conidium that generally functions as a resting spore ${ }^{1}$. These fungal structures contain very significant reserves which are activated and consumed during germination until the newly formed colony has developed sufficiently for its own trophic extension ${ }^{1,9}$.

Concluding, we emphasize that tomato juice agar is a well known medium used in Mycology laboratories, simple to prepare, cheap and that now, it can have a double usage indicating the sexual differentiation of yeasts and as a presumptive medium for differentiation between $C$. albicans and C. dubliniensis.

\section{RESUMO}

\section{Comparação do ágar suco de tomate com outros três meios, na diferenciação entre $C$. albicans e $C$. dubliniensis}

O presente estudo teve como objetivo comparar o ágar suco de tomate, um tradicional meio utilizado para observação de ascósporos em leveduras, com o ágar semente de niger, ágar caseína e ágar semente de girassol, na diferenciação fenotípica entre $C$. albicans e $C$. dubliniensis. Após $48 \mathrm{~h}$ de incubação a $30{ }^{\circ} \mathrm{C}$, os 26 isolados de $C$. dublinienis (100\%) evidenciaram a formação de clamidoconídios igualmente em todos os meios comparados. Entretanto, quando semeados com $C$. albicans, a formação de clamidoconídios foi raramente observada, resultando nos seguintes percentuais de ausência destas estruturas: ágar suco de tomate $(92,47 \%)$, ágar niger $(96,7 \%)$, ágar caseína $(91,39 \%)$, ágar semente de girassol $(96,7 \%)$. Estes resultados permitem-nos sugerir a utilização do ágar suco de tomate como mais um meio que, já no primo-isolamento, é capaz de, presuntivamente, diferenciar $C$. albicans de C. dubliniensis.

\section{REFERENCES}

1. ALEXOPOULOS, C.J.; MIMS, C.W. \& BLACKWELL, M. - Introductory Mycology 4. ed. New York, John Wiley, 1996.

2. AL MOSAID, A.; SULLIVAN, D.; SALKIN, I.F.; SHANLEY, D. \& COLEMAN, D.C. Differentiation of Candida dubliniensis from Candida albicans on Staib agar and caffeic acid-ferric citrate agar. J. clin. Microbiol., 39: 323-327, 2001

3. AL MOSAID, A.; SUlliVAN, D.J. \& COLEMAN, D.C. - Differentiation of Candida dubliniensis from Candida albicans on Pal's agar. J. clin. Microbiol., 41: 47874789, 2003.

4. ALVES, S.H.; MILAN, E.P.; SANT'ANA, P.L. et al. - Hypertonic Sabouraud broth as a simple and powerful test for Candida dubliniensis screening. Diagn. Microbiol. infect. Dis., 43: 85-86, 2002.

5. ALVES, S.H.; HORTA, J.A.; MILÁN, E.P. et al. - Carbohydrate assimilation profiles of Brazilian Candida dubliniensis isolates based on ID 32C system. Rev. Inst. Med. trop. S. Paulo, 47: 109-111, 2005. 


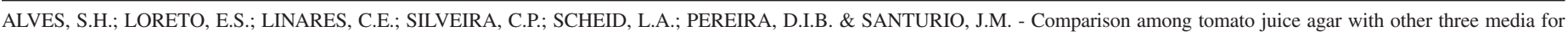
differentiation of Candida dubliniensis from Candida albicans. Rev. Inst. Med. trop. S. Paulo, 48(3):119-121, 2006.

6. BIKANDI, J.; MILLAN, R.S.; MORAGUES, M.D. et al. - Rapid identification of Candida dublinensis by indirect immunofluorescence based on differential localization of antigens on C. dubliniensis blastospores and Candida albicans germ tubes. J. clin. Microbiol., 36: 2428-2433, 1998.

7. GALES, A.C.; PFALLER, M.A.; HOUSTON, A.K. et al. - Identification of Candida dubliniensis based on temperature and utilization of xylose and $\propto$-methyl-Dglucoside as determined with API 20C AUX and Vitek YBC systems. J. clin. Microbiol., 37: 3804-3808, 1999.

8. GRAF, B.; TROST, A.; EUCKER, J.; GOBEL, U.B. \& ADAM, T. - Rapid and simple differentiation of $C$. dubliniensis from $C$. albicans. Diagn. Microbiol. infect. Dis., 48: 149-151, 2004.

9. JENNINGS, D.H. \& LYSEK, G. - Fungal Biology: understanding the fungal lifestyle. 2. ed. New York, Springer-Verlag, 1999.

10. KHAN, Z.U.; AHMAD, S.; MOKADDAS, E. \& CHANDY, R. - Tobacco agar, a new medium for differentiating Candida dubliniensis from Candida albicans. J. clin. Microbiol., 42: 4796-4798, 2004.

11. KIRKPATRICK, W.R.; REVANKAR, S.G.; McATEE, R.K. et al. - Detection of Candida dubliniensis in oropharyngeal samples from human immunodeficiency virus-infected patients in North America by primary CHROMagar Candida screening and susceptibility testing of isolates. J. clin. Microbiol., 36: 3007-3012, 1998.

12. KURZAI, O.; HEINZ, W.J.; SULLIVAN, D.J. et al. - Rapid PCR test for discrimination between Candida albicans and Candida dubliniensis isolates using primers derived from pH-regulated PHR1 and PHR2 genes of C. albicans. J. clin. Microbiol., 37: 1587-1590, 1999.

13. LARONE, D.H. - Medically important fungi: a guide to identification. 3. ed. Washington, ASM Press, 1995.

14. MOSCA, C.O.; MORAGUES, M.D.; LLOVO, J. et al. - Casein agar: a useful medium for differentiating Candida dubliniensis from Candida albicans. J. clin. Microbiol., 41: 1259-1262, 2003.
15. PELTROCHE-LLACSAHUANGA, H.; SCHMIDT, S.; SEIBOLD, M.; LUTTICKEN, R. \& HAASE, G. - Differentiation between Candida dubliniensis and Candida albicans by fatty acid methyl ester analysis using gas-liquid chromatography. $\mathbf{J}$. clin. Microbiol., 38: 3696-3704, 2000.

16. PINJON, E.; SUlLIVAN, D.; SALKIN, I.; SHANLEY, D. \& COLEMAN, D. - Simple, inexpensive, reliable method for differentiation of Candida dubliniensis from Candida albicans. J. clin. Microbiol., 36: 2093-2095, 1998.

17. SAMSON, R.A.; HOEKSTRA, E.S.; FRISVAD, J.C. \& FILTENBORG, O. - Introduction of food-borne fungi. 5. ed. Baarn, Centraalbureau voor Schimmelcultures, 1996.

18. SELVARANGAN, R.; LIMAYE, A.P. \& COOKSON, B.T. - Rapid identification and differentiation of Candida albicans and Candida dubliniensis by capillary-based amplification and fluorescent probe hybridization. J. clin. Microbiol., 40: 43084312, 2002.

19. SLIFKIN, M. - Tween 80 opacity responses of various Candida species. J. clin. Microbiol., 38: 4626-4628, 2000.

20. STAIB, P. \& MORSCHHAUSER, J. - Chlamydospore formation on Staib agar as a speciesspecific characteristic of Candida dubliniensis. Mycoses, 42: 521-524, 1999.

21. SUlliVAN, D.J.; WESTERNENG, T.J.; HAYNES, K.A.; BENNETT, D.E. \& COLEMAN, D.C. - Candida dubliniensis sp. nov.: phenotypic and molecular characterization of a novel species associated with oral candidosis in HIV-infected individuals. Microbiology, 141: 1507-1521, 1995.

22. SUlliVAN, D. \& COLEMAN, D. - Candida dubliniensis: characteristics and identification. J. clin. Microbiol., 36: 329-334, 1998.

Received: 15 August 2005

Accepted: 21 February 2006 